Supplement of Earth Surf. Dynam., 8, 679-693, 2020

https://doi.org/10.5194/esurf-8-679-2020-supplement

(c) Author(s) 2020. This work is distributed under

the Creative Commons Attribution 4.0 License.

(c) (1)

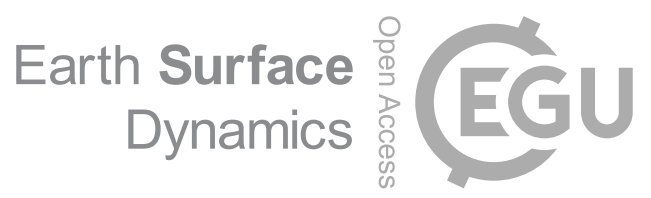

Supplement of

\title{
Holocene sea-level change on the central coast of Bohai Bay, China
}

Fu Wang et al.

Correspondence to: Fu Wang (wfu@cgs.cn)

The copyright of individual parts of the supplement might differ from the CC BY 4.0 License. 


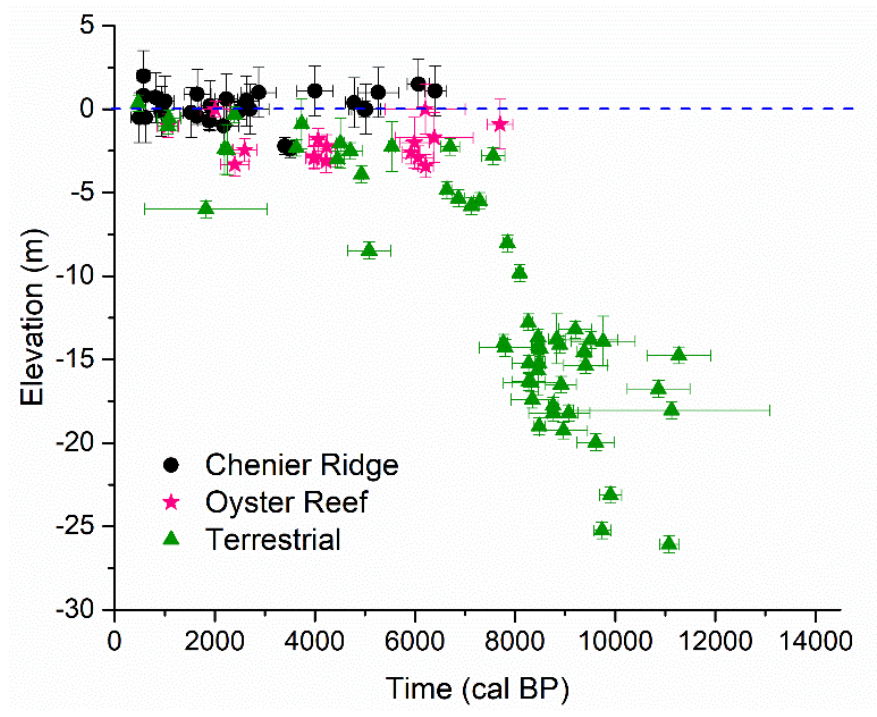

Fig. S2. The SLIPs compiled and corrected by Li et al. (2015). For chenier ridges marine mollusc shells were collected at the base of the ridges. Oyster shells were collected from muddy layer below and between the reefs. SLIPs from terrestrial material (peat, fresh-water molluscs, vegetation remains) are limiting points.

\section{SLIPs south of Bohai Bay}

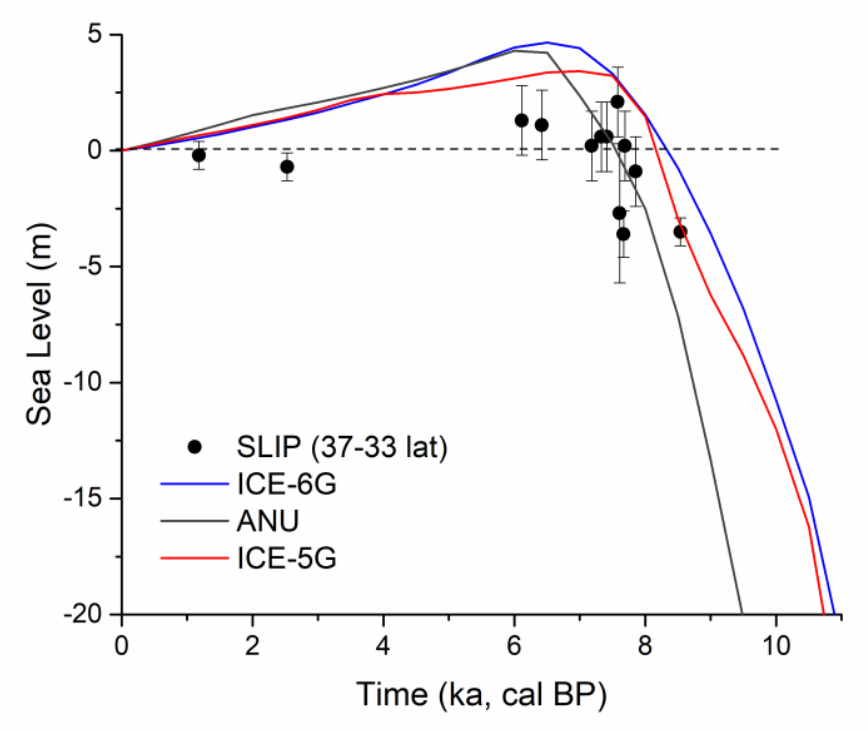

Fig. S3. The comparison of SLIPs generated for the coast south of Bohai Bay (latitude $37^{\circ} \mathrm{N}-33^{\circ} \mathrm{N}$; adopted from Lambeck et al., 2014) and GIA models employed in this study. 
Table S1. Parameters used by GIA models employed in this study (SELEN) compared the model established by Bradley et al. (2016; BRAD).

\begin{tabular}{l|cccc}
\hline Parameter/Result & BRAD & $\begin{array}{c}\text { ANU } \\
\text { (SELEN) }\end{array}$ & $\begin{array}{c}\text { ICE 5G } \\
\text { (SELEN) }\end{array}$ & $\begin{array}{c}\text { ICE 6G } \\
\text { (SELEN) }\end{array}$ \\
\hline $\begin{array}{l}\text { Lithospheric thickness } \\
\text { (km) }\end{array}$ & 96 & 65 & 90 & 90 \\
\hline $\begin{array}{l}\text { Upper mantle viscosity } \\
\text { (Pa s) }\end{array}$ & $<1.5 \times 10^{20}$ & $0.5 \times 10^{21}$ & $0.5 \times 10^{21}$ & $0.5 \times 10^{21}$ \\
\hline $\begin{array}{l}\text { Lower mantle viscosity } \\
\text { (Pa s) }\end{array}$ & $8 \times 10^{21}$ & $10 \times 10^{21}$ & $2.7 \times 10^{21}$ & $3.2 \times 10^{21}$ \\
\hline $\begin{array}{l}\text { Antarctic contribution to } \\
\text { ESL (m) and end of } \\
\text { melting (until ka) }\end{array}$ & 28 until 1 & 30 until 1 & 17.5 until 4 & 13.6 until 4 \\
\hline $\begin{array}{l}\text { Holocene highstand } \\
\text { (m@ka) }\end{array}$ & $<0.5 @ 7$ & 4.3 @ 6 & $3.4 @ 7$ & 4.7 @ 6.5 \\
\hline
\end{tabular}

Table S2. Survey data and lithostratigraphy of cores.

\begin{tabular}{|c|c|c|}
\hline $\begin{array}{l}\text { Depth } \\
(\mathrm{m})\end{array}$ & Alt. (m, asl) & Description \\
\hline \multicolumn{3}{|c|}{ Core DC01 (38 $40^{\prime} 09^{\prime \prime}, 116^{\circ} 39^{\prime} 10^{\prime \prime}$, ground altitude: $\left.+3.74 \mathrm{~m}\right)$} \\
\hline $1.0-6.50$ & 2.74 to -2.76 & Yellowish brown to grey clayey silt with rusting stains \\
\hline $6.5-9.40$ & -2.76 to -5.66 & Yellowish grey silty clay with black peat layers in various depths \\
\hline $9.4-12.6$ & -5.66 to -8.86 & Brown grey clayey silt with calcium nucleus at base (Pre-Holocene) \\
\hline \multicolumn{3}{|c|}{ Core QX01 (3838'52", $116^{\circ} 48^{\prime} 58^{\prime \prime}$, ground altitude: $\left.+5.16 \mathrm{~m}\right)$} \\
\hline $1.0-5.00$ & 4.16 to 0.16 & Brown to grey clayey silt with thick laminations and rusting stains \\
\hline $5.0-9.10$ & 0.16 to -3.94 & $\begin{array}{l}\text { Brownish grey clayey silt with thin ( } 5 \mathrm{~cm} \text { thick) layers of charcoal, organic } \\
\text { material and shell fragments in various depths }\end{array}$ \\
\hline $9.1-11.4$ & -3.94 to -6.24 & Brownish grey clayey silt with small amount of charcoal and shell fragments \\
\hline $\begin{array}{l}11.4- \\
13.8\end{array}$ & -6.24 to -8.64 & $\begin{array}{l}\text { Grey to brownish grey clayey silt laminations, with black peat layers and a } \\
\text { sharp contact at upper boundary }\end{array}$ \\
\hline $\begin{array}{l}13.8- \\
19.6\end{array}$ & -8.64 to -14.4 & Yellowish brown sandy silt (Pre-Holocene) \\
\hline \multicolumn{3}{|c|}{ 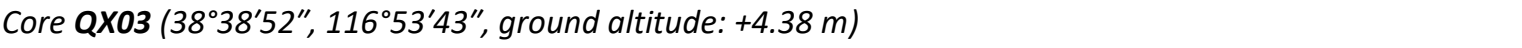 } \\
\hline $1.2-4.8$ & 3.18 to -0.42 & $\begin{array}{l}\text { Dark brown clayey silt with small amount of charcoal. Calcium nucleus and } \\
\text { shells in } 2.9-3.1 \mathrm{~m} \text { depth }\end{array}$ \\
\hline $4.8-8.9$ & -0.42 to -4.52 & $\begin{array}{l}\text { Dark greyish brown clayey silt with laminations and small amount of shell } \\
\text { fragments }\end{array}$ \\
\hline 8.9-13.7 & -3.52 to -9.32 & Greyish brown to grey clayey silt with a black peat layer in $12.4-12.5 \mathrm{~m}$ depth \\
\hline $\begin{array}{l}13.7- \\
16.0\end{array}$ & -9.32 to -11.6 & Brown clayey silt, with rusting stains and thick laminations (Pre-Holocene) \\
\hline \multicolumn{3}{|c|}{ Core QX02 (38 $38^{\prime} 24^{\prime \prime}, 116^{\circ} 57^{\prime} 24^{\prime \prime}$, ground altitude: $\left.+3.57 \mathrm{~m}\right)$} \\
\hline $1.0-3.90$ & 2.57 to -0.33 & Yellowish brown clayey silt with small amount of charcoal \\
\hline $3.9-11.3$ & -0.33 to -7.73 & $\begin{array}{l}\text { Brownish grey clayey silt, with shell fragments and rusting stains, and several } \\
\text { organic-rich layers }\end{array}$ \\
\hline $\begin{array}{l}11.3- \\
16.6\end{array}$ & -7.73 to -13.0 & $\begin{array}{l}\text { Yellowish brown clayey silt, with charcoal and fine sand at base, and black } \\
\text { peat layers }\end{array}$ \\
\hline $\begin{array}{l}16.6- \\
20.3\end{array}$ & -13.0 to -16.7 & $\begin{array}{l}\text { Yellowish brown clayey silt, with calcium nucleus developed in various sizes } \\
\text { (Pre-Holocene) }\end{array}$ \\
\hline \multicolumn{3}{|c|}{ 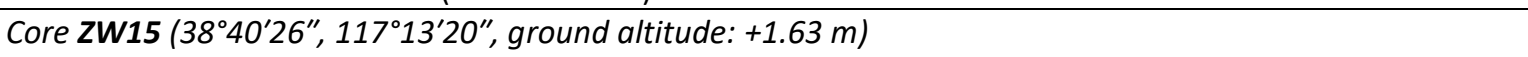 } \\
\hline $0.8-2.2$ & 0.83 to -0.57 & $\begin{array}{l}\text { Brown clayey silt, with rusting stains, laminations and an increase in organic } \\
\text { matter at } 1.60 \mathrm{~m} \text { of depth }\end{array}$ \\
\hline $2.2-12.6$ & -0.57 to -10.97 & $\begin{array}{l}\text { Greyish brown clayey silt, with small amount of marine shells, laminations } \\
\text { throughout }\end{array}$ \\
\hline
\end{tabular}




\begin{tabular}{|c|c|c|}
\hline $\begin{array}{l}\text { Depth } \\
(\mathrm{m})\end{array}$ & Alt. (m, asl) & Description \\
\hline $\begin{array}{l}12.6- \\
15.2\end{array}$ & -10.97 to -13.57 & Grey clayey silt with peat layers at various depths \\
\hline $\begin{array}{l}15.2- \\
17.0\end{array}$ & -13.57 to -15.37 & $\begin{array}{l}\text { Dark yellowish brown clayey silt, with rusting stains and calcium nucleus (Pre- } \\
\text { Holocene) }\end{array}$ \\
\hline \multicolumn{3}{|c|}{ Core Q7 (38 39'24", $117^{\circ} 31^{\prime} 27^{\prime \prime}$, ground altitude: $\left.+3.46 \mathrm{~m}\right)$} \\
\hline $0.0-7.0$ & 3.46 to -3.54 & Brown silt, with laminations and marine shells \\
\hline 7.0-18.7 & -3.54 to -15.24 & Dark grey clayey silt, with shell fragments \\
\hline $\begin{array}{l}18.7- \\
18.9\end{array}$ & -15.24 to -15.44 & $\begin{array}{l}\text { Dark brown peaty clay overlying yellowish brown sandy sediment (the latter } \\
\text { as Pre-Holocene) }\end{array}$ \\
\hline $\begin{array}{l}18.9- \\
25.0\end{array}$ & -15.44 to -21.54 & Yellowish brown silt sand (Pre-Holocene) \\
\hline \multicolumn{3}{|c|}{ 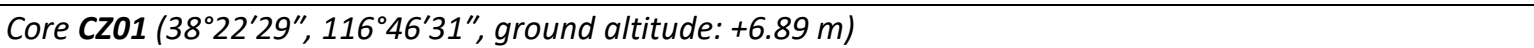 } \\
\hline $1.0-6.4$ & 5.89 to 0.49 & $\begin{array}{l}\text { Dark brown clayey silt, with fine laminations, charcoal, Fe/Mn concretion, } \\
\text { and freshwater snails }\end{array}$ \\
\hline $6.4-15.4$ & 0.49 to -8.51 & $\begin{array}{l}\text { Dark yellowish brown clayey silt, with rusting stains and calcium nucleus. } \\
\text { Black peat layers in various depths }\end{array}$ \\
\hline $\begin{array}{l}15.8- \\
20.0\end{array}$ & -8.91 to -13.11 & Very dark greyish brown to very dark grey silt (Pre-Holocene) \\
\hline \multicolumn{3}{|c|}{ 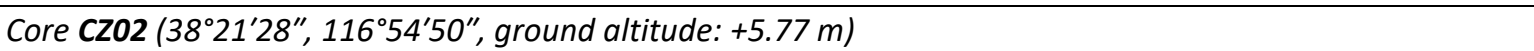 } \\
\hline $1.0-4.4$ & 4.77 to 1.37 & Dark yellowish brown clayey silt, with Fe/Mn concretion. \\
\hline $4.4-15.0$ & 1.37 to -9.23 & $\begin{array}{l}\text { Brown to light greyish brown silt, with laminations, rusting stains and calcium } \\
\text { nucleus. Black peat layers at various depths }\end{array}$ \\
\hline $\begin{array}{l}15.0- \\
20.0\end{array}$ & -9.23 to -14.23 & Yellowish brown silt, with rusting stains and calcium nucleus (Pre-Holocene) \\
\hline \multicolumn{3}{|c|}{ Core CZ03 (38 $22^{\prime} 19^{\prime \prime}, 117^{\circ} 06^{\prime} 29^{\prime \prime}$, ground altitude: $\left.+3.94 \mathrm{~m}\right)$} \\
\hline $1.0-4.4$ & 2.94 to -0.46 & Dark yellowish brown clayey silt, with rusting stains and $\mathrm{Fe} / \mathrm{Mn}$ concretion \\
\hline 4.4-9.3 & -0.46 to -5.36 & $\begin{array}{l}\text { Dark grey brown clayey silt, with laminations and shell fragments. Organic } \\
\text { clay and peat in various depths }\end{array}$ \\
\hline $9.3-15.0$ & -5.36 to -11.06 & Grey silt with charcoal and two black peat layers \\
\hline $\begin{array}{l}15.0- \\
16.0\end{array}$ & -11.06 to -12.06 & Yellowish brown sandy silt (Pre-Holocene) \\
\hline \multicolumn{3}{|c|}{ Core CZ87 (38³1'39", $116^{\circ} 54^{\prime} 38^{\prime \prime}$, ground altitude: $\left.+4.46 \mathrm{~m}\right)$} \\
\hline $0.0-5.8$ & 4.46 to -1.34 & $\begin{array}{l}\text { Light grey to brown clayey silt, with laminations, Fe/Mn concretions and } \\
\text { rusting stains }\end{array}$ \\
\hline $5.8-11.5$ & -1.34 to -7.04 & Yellowish brown clayey silt, with small amount of shell fragments \\
\hline $\begin{array}{l}11.5- \\
16.0\end{array}$ & -7.04 to -11.54 & Grey clayey silt, with charcoal, laminations and black peats \\
\hline $\begin{array}{l}16.0- \\
20.0\end{array}$ & -11.54 to -15.54 & Greyish brown silt (Pre-Holocene) \\
\hline \multicolumn{3}{|c|}{ Core CZ61 (38 $33^{\prime} 29^{\prime \prime}, 116^{\circ} 58^{\prime} 50^{\prime \prime}$, ground altitude: $\left.+3.76 \mathrm{~m}\right)$} \\
\hline $0.0-4.5$ & 3.76 to -0.74 & Yellowish brown clayey silt and silt, with charcoal \\
\hline 4.5-9.7 & -0.74 to -5.94 & $\begin{array}{l}\text { Brown to grey clayey silt, with marine shell fragments. Organic clay at various } \\
\text { depths }\end{array}$ \\
\hline $9.7-14.7$ & -5.94 to -10.94 & Very dark grey clayey silt, with laminations. Peats in various depths \\
\hline $\begin{array}{l}14.7- \\
18.0\end{array}$ & -10.94 to -14.24 & $\begin{array}{l}\text { Yellowish brown clayey silt, with laminations and small amount of calcium } \\
\text { nucleus (Pre-Holocene) }\end{array}$ \\
\hline \multicolumn{3}{|c|}{ 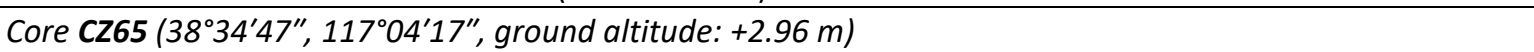 } \\
\hline $0.0-3.8$ & 2.96 to -0.84 & Dark brown clayey silt, with laminations and charcoal \\
\hline $3.8-9.7$ & -0.84 to -6.74 & $\begin{array}{l}\text { Grey silt, with rusting stains, laminations and charcoal in upper and lower } \\
\text { ends, marine shells in the middle }\end{array}$ \\
\hline $9.7-13.8$ & -6.74 to -10.84 & Grey clay and silt, with laminations and charcoal and a black peat layer \\
\hline $\begin{array}{l}13.8- \\
16.6\end{array}$ & -10.84 to -13.64 & $\begin{array}{l}\text { Brown to grey brown clayey silt, with Fe/Mn concretion, calcium nucleus and } \\
\text { freshwater snails (Pre-Holocene) }\end{array}$ \\
\hline
\end{tabular}




\begin{tabular}{|c|c|c|}
\hline $\begin{array}{l}\text { Depth } \\
\text { (m) }\end{array}$ & Alt. (m, asl) & Description \\
\hline $0.0-5.4$ & 6.42 to 1.02 & $\begin{array}{l}\text { Light yellowish brown to greyish brown clayey silt, with laminations, rusting } \\
\text { stains, charcoals and dark grey peats }\end{array}$ \\
\hline 5. 4-10.0 & 1.02 to -3.58 & Dark grey clayey silt and fine silt, with organic clay in various depths \\
\hline $\begin{array}{l}10.0- \\
14.0\end{array}$ & -3.58 to -7.58 & $\begin{array}{l}\text { Grey fine silt and clayey slit, with rusting stains and charcoal. Black peats in } \\
\text { various depths }\end{array}$ \\
\hline $\begin{array}{l}14.0- \\
17.0\end{array}$ & -7.58 to -10.58 & Yellowish brown clayey silt, with laminations in upper layer (Pre-Holocene) \\
\hline \multicolumn{3}{|c|}{ Core CZ85 (3828'09", $117^{\circ} 01^{\prime} 10^{\prime \prime}$, ground altitude: $\left.+4.61 \mathrm{~m}\right)$} \\
\hline $0.5-3.6$ & 4.11 to 1.01 & $\begin{array}{l}\text { Dark yellowish brown clayey silt, with plant roots at surface, and charcoals, } \\
\text { Fe/Mn concretions in the lower part }\end{array}$ \\
\hline $3.6-8.8$ & 1.01 to -4.19 & $\begin{array}{l}\text { Brown clayey silt, with rusting stains, charcoals. Organic clay in various } \\
\text { depths }\end{array}$ \\
\hline $8.8-15.8$ & -4.19 to -11.19 & Dark grey silt, with charcoal and black peats \\
\hline $\begin{array}{l}15.8- \\
17.7\end{array}$ & -11.19 to -13.09 & Light grey clayey silt, with a few calcium nucleus at base (Pre-Holocene) \\
\hline \multicolumn{3}{|c|}{ Core CZ66 $\left(38^{\circ} 31^{\prime} 29^{\prime \prime}, 117^{\circ} 07^{\prime} 59^{\prime \prime}\right.$, ground altitude: $\left.+3.87 \mathrm{~m}\right)$} \\
\hline $1.0-3.6$ & 2.87 to 0.27 & Yellowish brown clayey silt, with Fe/Mn concretion in lower part \\
\hline $3.6-6.3$ & 0.27 to -2.43 & Yellowish brown clayey silt, with charcoal and organic clay in various depths \\
\hline $6.3-10.8$ & -2.43 to -6.93 & Yellowish brown silt, with rusting stains and small amount of marine shells \\
\hline $\begin{array}{l}10.8- \\
14.0\end{array}$ & -6.93 to -10.13 & Light yellowish grey to grey silt and clay, with charcoal and black peats \\
\hline $\begin{array}{l}14.0- \\
16.6\end{array}$ & -10.13 to -12.73 & $\begin{array}{l}\text { Greyish brown clayey silt, with Fe/Mn concretion, freshwater snails and } \\
\text { shells (Pre-Holocene) }\end{array}$ \\
\hline
\end{tabular}

\section{References}

Bradley, S.L., Milne, G.A., Horton, B.P., Zong, Y.Q.: Modelling sea level data from China and Malay-Thailand to estimate Holocene ice-volume equivalent sea level change. Quaternary Science Reviews, 137, 54-68. DOI: 10.1016/j.quascirev.2016.02.002, 2016.

Cang, S.X., Zhao, S.L., Zhang, H.C., Huang, Q.F.: Middle Pleistocene paleoecology, paleoclimatology and paleogeography of the western coast of Bohai Gulf. Acta Palaeontologica Sinica 18(6): 579-591. DOI: 10.19800/j.cnki.aps.1979.06.006, 1979 (in Chinese with English abstract).

Geng, X.S.: Marine transgressions and regressions in east China since late Pleistocene Epoch. Acta Oceanlogica Sinica, 3(1), 114-130.

http://www.hyxb.org.cn/aos/ch/reader/create_pdf.aspx?file_no=19810110\&flag=\&journal_id=aos\&year_id =1981, 1981 (in Chinese with English abstract).

Geng, X.S., Fu, M.Z., Cheng, Z.B.: The biologic geology and chronology of the shelly cheniers in Hebei-Tianjin coastal plain. In Liang, M.S., Zhang, J.L. eds. Correlation of onshore and offshore Quaternary in China. Beijing: Science Press, 1991, 68-78 (in Chinese with English abstract).

Lambeck, K., Rouby, H., Purcell, A., Sun, Y., Sambridge, M., 2014. Sea level and global ice volumes from the Last Glacial Maximum to the Holocene. Proceedings of the National Academy of Sciences, 111, 15296-15303.

Li, J.F.; Kang, H.; Wang, H.; Pei, Y.D.; Modern geological action and discussion of influence facters on the west coast of Bohai Bay, China. Geological Survey and Research, 30(4), 295-301. http://www.tianjin.cgs.gov.cn/dzdcyyj/qkxz/20074/200801/P020160920812081540884.pdf, 2007 (in Chinese with English abstract). 
Li, J., Shang, Z., Wang, F., Chen, Y., Tian, L., Jiang, X., Wang, H.: Holocene sea level change on the west coast of the Bohai Bay. Quaternary Sciences, 35(2), 243-264. DOI: 10.11928/j.issn.1001-7410.2015.02.01, 2015 (in Chinese with English abstract).

Lin, J.X.: Preliminary notes on Quaternary transgressions and regressions in N. China Plain. Acta Geological Sinica, 2, 109-116. DOI: CNKI:SUN:DZXE.0.1977-02-001, 1977 (in Chinese with English abstract).

Qin, L., Shang, Z.W., Li, Y., Li, J.F.: Temporal and spatial distribution of the oyster reef in Biaokou to Zengkouhe area; Geological Survey and Research, 40(4), 306-310.

http://www.tianjin.cgs.gov.cn/dzdcyyj/qkxz/20174/201802/P020180202566954723921.pdf, 2017 (in Chinese with English abstract).

Su, S.W., Shang, Z.W., Wang, F., Wang, H.: Holocene Chenier: spatial and temporal distribution and sea level indicators in Bohai Bay. Geological Bulletin of China, 30(9), 1382-1395. DOI: 10.1007/s11589-011-0776-4, 2011(in Chinese with English abstract).

Wang, H., Jia L., Wu P. Jiang, L., Hu, B. Xiang, L.: Effects of last-deglaciation on the historical relative sea levels of East Asia Seas and the implications. Chinese Journal of Geophysics, 55(4), 1144-1153. DOI: 10.6038/j.issn.0001-5733.2012.04.010, 2012.

Wang, H.: Chronology of Holocene chenier and oyster reefs on the coast of Bohai Bay, China. Quaternary Research, 47, 192-205. DOI: 10.1006/qres.1996.1865, 1997.

Wang, H., Fan, C.F., Li, J.F., Li, F.L., Yan, Y.Z., Wang, Y.S., Zhang, J.Q., Zhang, YF.: Holocene oyster reefs on the northwest coast of the Bohai Bay, China. Geological bulletin of China, 25(3), 315-331.

http://dzhtb.cgs.cn/gbc/ch/reader/create_pdf.aspx?file_no=20060354\&flag=1\&year_id=2006\&quarter_id=3 , 2006 (in Chinese with English abstract).

Wang, Y.: The shell coast ridges and the old coastlines of the west coast of the Bohai Bay. Bulletin of Nanjing University (Edition of Natural Sciences), 8(3), 424-440. DOI: CNKI:SUN:NJDZ.0.1964-03-007, 1964 (with three plates) (in Chinese with English abstract).

Wang, Y.M.: A preliminary study on the Holocene transgression on the coastal plain along the north-western Bohai Bay. Geographical Research, 1(2), 59-69. DOI: 10.11821/yj1982020007, 1982 (in Chinese with English abstract).

Xia, D.X.: Where was the Mid-Holocene highstand. Acta Oceanologica Sinica, 3(4), 601-609. http://www.hyxb.org.cn/aos/ch/reader/create_pdf.aspx?file_no=19810410\&flag=1\&journal_id=aos\&year_i $\mathrm{d}=1981,1981$.

Xie, Z.R., Yan, L.W. and Lv, G.N.: Systematic change on sea surface and land surface: reconstruction, Monitoring and prediction. Beijing: Science Press, 2012, 1-370.

Xu, J.S.: Cheniers and sea level changes in Huanghua coast, Bohai Bay. Marine Science Bulletins, 1, 62-72. http://www.hyxb.org.cn/aos/ch/reader/create_pdf.aspx?file_no=19940109\&flag=\&journal_id=aos\&year_id =1994, 1994 (in Chinese with English abstract).

Yang, H.R. and Chen, Q.X.: Quaternary transgressions, eustatic changes and shifting of shoreline in east China. Marine Geology \& Quaternary Geology, 5(4), 69-80. DOI: 10.16562/j.cnki.0256-1492.1985.04.011, 1985 (in Chinese with English abstract).

Yang, Z.G., Li, Y.J., Ding Q.L., He, B.C.: Some fundamental problems of Quaternary geology of eastern Hebei Plain. Acta Geologica Sinica, 4, 263-281. DOI: CNKI:SUN:DZXE.0.1979-04-000, 1979 (in Chinese with English abstract).

Zhang, Y.C., Hu, J.J. and Liu, C.F.: Preliminary recognition of sea and land changes along the east coast of China since the terminal Pleistocene. Bulletin of the Chinese Academy of Geological Sciences, 19, 37-52. 
https://www.ixueshu.com/document/8e1a59a8c6fd86ca318947a18e7f9386.html, 1989 (in Chinese with English abstract).

Zhao, S.L., Yang, G.F., Cang, S.X., Zhang, H.C., Huang, Q.F., Xia, D.X., Wang, Y.J., Liu, F.S., Liu, C.F.: On the marine stratigraphy and coastlines of the western coast of the gulf of Bohai. Oceanologia Et Limnologia Sinica, 9(1), 15-25

http://qdhys.ijournal.cn/hyyhz/ch/reader/create_pdf.aspx?file_no=19780102\&flag=\&journal_id=hyyhz\&yea r_id=1978, 1978 (in Chinese with English abstract).

Zhao, X.T., Geng, X.S., Zhang, J.W.: Sea level changes of the eastern China during the past 20000 years. Acta Oceanologia Sinica, 1(2), 269-281.

http://www.hyxb.org.cn/aos/ch/reader/create_pdf.aspx?file_no=19790208\&year_id=1979\&quarter_id=2\&f alg=1, 1979. 